declivity " an escarpment," comparing it with true escarpments in England and France, and with the cliff-borders of the Nile valley (which are not technically escarpments). He says "all these escarpments have been formed over the surface of emergent lands," that they are absolutely terrestrial, and "that in ascribing a similar origin to those here under consideration we are only drawing a logical deduction from the premises laid down."

The logic of this does not seem very clear. Can Prof. Hull point to a true escarpment anywhere in Europe which has a length of 700 miles and a height above its base of 7,000 to 8,000 feet? Moreover, this so-called escarpment does not stop in the Bay of Biscay ; it is continued round the coasts of Spain, it crosses the mouth of the Mediterranean, and runs down the whole length of Africa. It is part of the elevated shelf on which two continents stand, and Prof. Hull may call it an escarpment if he chooses, but it is not comparable with ordinary escarpments, and he is not justified in assuming that it has been formed by atmospheric agencies.

$\mathrm{He}$ also tells your readers that "a solid escarpment of this kind indicates a slow continuous elevation after the British platform had been planed down by wave action, and subsequent depression after a lapse of time." Here he assumes that the platform was formed first and the escarpinent afterwards. I think most writers have supposed that the great declivity which marks the ancient border of the continent is a much older feature than the platform.

Finally, we are told that the formation of the platform "may be referred back with confidence to the Mio-Pliocene period, and that of the grand escarpment to the succeeding. early Pleistocene or Glacial stage." There are probably others beside myself who would like to have the reasons for this confident assertion. Is there any reason why the formation of the escarpment and the union of Great Britain with Iceland should not have taken place in the Eocene period? That such a union may have been repeated at a later date is quite possible, but I think the history of the features described by Prof. Hull is much longer and more complicated than he supposes, and I would not like to say that either of them was formed wholly at any one period.

Prof. Hull may have good reasons for his statements, but he does not give them, and as his conclusions are not the only inferences that may be drawn from the facts, they must be discussed before they can be accepted.

A. J. JuKES-BROWNE.

\title{
VERTEBRATE PALAOXTOLOGY.
}

Srk,-While thanking you for the gratifying review with which my "Outlines of Vertebrate Palæontology" are honoured in the August number of the Geologicar Magazine, I should like to correct two misapprehensions of the reviewer.

Firstly, it is a mistake to suppose that any "new terms are introduced." All the terms empioyed are to be found in current literature, and most of them are in nearly universal use. Moreover, on its first mention each term which is not likely to be familiar to the elementary student, is not only printed in italics and briefly defined, 
but also indexed for ready reference. Under these circumstances the editor and author considered a special glossary to be superfluous.

Secondly, your reviewer is mistaken in describing the lettering of fig. 91, p. 143, as the result of undigested compilation. The interpretation of the squamosal and supratemporal bones in the Squamata there given, is intentional, and based especially upon the researches of my colleague, Mr. Boulenger. Anyone interested in the subject may refer to the figures of the skulls of the Agamoid Calotes and the typical Varanoid, Varanus, given in his volume on Reptiles and Batrachians contributed to Dr. Blanford's "Fauna of British India." He seems to demonstrate clearly that in Lacertilia the squamosal always retains its normal connection with the postfrontal in front, but eventually separates from the parietal behind; while the supratemporal in that case slips backward to occupy the cleft thus formed.

I am much indebted to your reviewer for pointing out that the legend of fig. 185 (Palaotherium) only applies to the true molars, not to the fourth premolar, which, I had omitted to observe, bears the same lettering. In the matter of new illustrations, I have met with unusually liberal treatment at the hands of the publishers ; but it was unfortunately impossible to dispense with borrowed electrotypes, and hence the non-uniformity of lettering which is sometimes perplexiug.

A. Smith Woonward.

\section{OBITUARY.}

\section{JAMES HALL.}

Bors SepteMber 12, 1811.

Died August 7, 1898.

By the death of Professor James Hall geology bas lost its oldest and one of its most distinguished leaders. He was born at the quaint old town of Hingham on the south shore of Boston Bay, and was educated at the Rensselaer Polytechnic Institute at Troy, and at the age of twenty-five received an appointment on the Geological Survey of New York State. Two years later he issued his first original scientific contribution, $\rightarrow$ a short note on some trilobites. His official duties were connected with both stratigraphy and palæontology, and at first he was apparently more interested in the former branch of geology. He studied the recession of the Niagara Falls and acted as guide to Lyell, who visited the Falls in 1841. In 1843 Hall was appointed State Palæontologist, in which capacity he wrote or edited no fewer than thirteen large imperial quarto volumes on the Palæontology of New York, which bave been issued at intervals between 1847 and 1894. The first volumes of this series formed the most magnificent contribution to extra-European Palæontology that had been issued at that time, and some of the later volumes are still the richest mine of information on some branches of Devonian palæontology. In addition to the extensive series of new fossils described in these monographs, Hall published many further important additions to American Palæontology in the reports of other State Surveys, as of Iowa, Wisconsin, and Missouri, and in papers in various 